\title{
The fast and of low-cost-adsorbent to the removal of cationic and anionic dye using chicken eggshell with its membrane
}

\author{
Linda Hevira ${ }^{1,2, *}$, Azimatur Rahmi ${ }^{1}$, Rahmiana Zein ${ }^{2}$, Zilfa $^{3}$, and Rahmayeni ${ }^{4}$ \\ ${ }^{1}$ Department of Pharmacy, Mohammad Natsir University, Bukittinggi 26116, Indonesia. \\ ${ }^{2}$ Laboratory of Analytical Environmental Chemistry, Department of Chemistry, Andalas University, \\ Padang 25163, Indonesia \\ ${ }^{3}$ Laboratory of Analytical Chemistry, Department of Chemistry, Andalas University, Padang 25163, Indonesia \\ ${ }^{4}$ Laboratory of Material Inorganic Chemistry, Department of Chemistry, Andalas University, \\ Padang 25163, Indonesia
}

\begin{abstract}
The use of the chicken eggshell with its membrane as low-cost adsorbent had been done to the removal of synthetic dyes in aqueous solution. Adsorption method in the batch system was done to adsorb Methylene Blue and Indigo Carmine as the cationic and anionic dyes. Some parameters were studied such as $\mathrm{pH}$, contact time, initial concentration of dyes and mass of ES+M to find the optimum adsorption. The functional group of ES+M like hydroxyl, amine, carboxyl and thiol were used to binding the dyes. The characteristics of ES+M were determined by FTIR and XRF to analyzed functional group and elements composition before and after adsorption. The adsorption capacity optimum of ES+M to adsorb Methylene Blue was $11.54 \mathrm{mg} / \mathrm{g}$ with \% RE $92.34 \%$ in 30 minutes, and Indigo Carmine was $8.04 \mathrm{mg} / \mathrm{g}$ with \% RE $64.34 \%$ in 15 minutes.
\end{abstract}

Keywords: Adsorption; eggshell; Methylene blue; Indigo carmine; wastewater treatment.

\section{Introduction}

Increasing population growth and rapid industry, has increased the amount of waste that enters the environment. The waste-water like synthetic dyes come from the textile industry, printing, plastic, coloring household and other materials. The synthetic dyes can be coloring the water even in small concentrations. The presence of dyes in waste-water reduces sunlight penetration to photosynthesis and acute toxicity to aquatic life ${ }^{1}$.

These dyes adversely affect human health, such as eye irritation, skin irritation, mutagenic, and carcinogenic $^{2,3}$.

Various ways in overcoming the problem of dye waste both physically and chemically have been widely reported, such as chemical coagulation ${ }^{4}$, activated sludge 5 , biodegradation ${ }^{6}$, photocatalysis 7 , photocatalysis and magnetically separation 8 , oxidation ${ }^{9}$, membrane technologies of reverse osmosis and nanofiltration ${ }^{10}$.

One of those methods was adsorption that is currently being developed due to easy and environmentally friendly to adsorb wastewater ${ }^{11}$. Adsorption used geomaterials such as natural zeolite to remove nutrients from livestock wastewater ${ }^{12}$, Thai bentonite

*Corresponding author: Linda Hevira

Email address: lindahevira@gmail.com

DOI: http://dx.doi.org/10.13171/mjc02003261271lh to adsorb aflatoxin $\mathrm{B} 1{ }^{13}, \mathrm{ZnO}$ to adsorb aliphatic dicarboxylic acids ${ }^{14}$ and polymers to adsorb methylene blue ${ }^{15}$. Meanwhile, adsorption used natural adsorbents derived from plants and animals (biomaterials) that are more environmentally friendly, high efficiency, easily obtained while reducing organic solid waste. This method is the most widely used because it is safe, does not give side effects that endanger health, does not require complicated and expensive equipment ${ }^{16}$.

Several studies on the use of biomaterials from plants have been carried out, such as apricot stone ${ }^{17}$, activated carbon cocoa ${ }^{18}$, mango seeds ${ }^{19}$, pine fruits ${ }^{20}$, orange peels ${ }^{21}$, gherkin leaves powder ${ }^{21}$, melon peels ${ }^{22}$, Tunisian palm ${ }^{23}$, okra seeds ${ }^{24}$, several plants bark ${ }^{25}$ and from animals like chitosan modified to adsorb metal ion ${ }^{26,27,28}$ and eggshell. Eggshells are waste by-products of eggs that produced several tons per day that sent to the landfill with high management cost. Eggshells mostly contain calcium carbonate ${ }^{29,30}$ which is often used as a calcium supplement, fertilizer, cosmetic from the membrane of eggshell, dental preparation, and other uses ${ }^{31}$.

Several studies have made eggshells as adsorbents, such as fluoride absorption ${ }^{32}$, removal of $\mathrm{Ni}^{33}$, and $\mathrm{H}_{2} \mathrm{~S}^{34}$. The ability of the eggshell to adsorb pollutant

Received January 20, 2020

Accepted February 3, 2020

Published March 26, 2020 
due to it has many pores, and the membrane of eggshells have a functional group that could be binding with cation or anion compound ${ }^{35}$. The eggshell was used as low-cost adsorbent ${ }^{36}$ to adsorb dyes in textile and batik ${ }^{37}$ industry in Indonesia as a developing country to removal dyes in wastewater. The membrane of the eggshell has an amino acid that has functional group such as amine that contacted with anionic dyes. In contrast, hydroxyl, carboxyl and a sulfonic group can interact with cationic dyes. Even though of membrane eggshell higher adsorption capacity, but Pramanpol and Nitayapat report that eggshell without membrane and eggshell with the membrane in the difference of absorption capacity is not too significant ${ }^{38}$.

The aim of this research to utilize eggshells with its membrane $(\mathrm{ES}+\mathrm{M})$ to adsorb synthetic dyes, and comparison of adsorption capacity and \% Removal of efficiency of ES+M to adsorb Methylene Blue and Indigo Carmine as representative of cationic and anionic dyes. The study was conducted with a batch method by finding the optimum conditions of adsorption with parameter variations: $\mathrm{pH}$, contact time, initial concentration, and mass of eggshells in small particle size of $36 \mu \mathrm{m}$ to expand the surface area to interact between $\mathrm{ES}+\mathrm{M}$ and dyes. Characterization of the ES+M with FTIR and XRF analyzed to know which part of the functional group was actively adsorbing dyes, and the elements contained in the<smiles>CN(C)c1ccc2nc3cc/c(=[N+](/C)Cl)cc-3sc2c1</smiles>

a. Methylene Blue
$\mathrm{ES}+\mathrm{M}$ before and after adsorption.

\section{Experimental section}

\subsection{Adsorbent preparation}

The adsorbent of the eggshell with its membrane $(\mathrm{ES}+\mathrm{M})$ is collected from Bukittinggi, West Sumatera, Indonesia. The physically treated of ES+M was cleaned with water, air-dried, ground by (Turbo 8099 ) in processed temperature $\leq 60^{\circ} \mathrm{C}$ and sifted with particle size $\leq 425 \mu \mathrm{m}$.

\subsection{Activation adsorbent}

The chemically-treated of ES+M was soaked as much as $25 \mathrm{~g}$ in $75 \mathrm{~mL} 0.01 \mathrm{~N} \mathrm{HNO}_{3}$ for 2 hours, then neutralized by added aqua dest 39,40 . The aimed of adding $\mathrm{HNO}_{3}$ was to remove the impurity and opened the pore of eggshell. Furthermore, the ES+M was dried, ground and sifted with particle size $\leq 36 \mu \mathrm{m}$ and ready to used.

\subsection{Preparation of Solution}

$0.250 \mathrm{~g}$ Methylene Blue (MB) dissolved with $250 \mathrm{~mL}$ distilled water in a volumetric flask. Then a variation of the concentration of Methylene Blue dye was made with multilevel dilution to create a calibration curve for a standard solution with differences in concentrations of $0,2,4,6,8,10 \mathrm{mg} / \mathrm{L}$. The same thing was done to make Indigo Carmine (IC) dye solution.

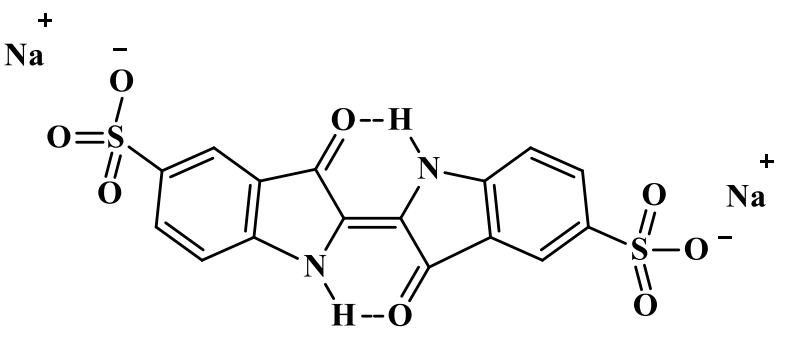

\section{b. Indigo Carmine}

Figure 1. Structure of Methylene Blue (cationic dye) and Indigo Carmine (anionic dye)

\subsection{Determination of Optimum Adsorption of dyes by biosorbents}

Several parameters such as $\mathrm{pH}$, contact time, initial concentration of dyes and mass of adsorbent were done. 0.1 - $1 \mathrm{~g}$ eggshell was added into $25 \mathrm{~mL}$ of Methylene Blue and Indigo carmine (10 - $50 \mathrm{mg} / \mathrm{L})$ with adding $\mathrm{HNO}_{3}$ and $\mathrm{NaOH}$ to adjust $\mathrm{pH}$ ranging from $2-10$. The agitation time was done ranging from 15 - 60 minutes on $100 \mathrm{rpm}$. The solution of Methylene Blue and Indigo carmine after contacted on ES+M were filtered and analyzed by Spectrophotometry UV-vis (Shimadzu).

The adsorption capacity of removal dye (Eq. 1) was calculated as follows:

$q e=\frac{(\mathrm{Co}-\mathrm{Ce}) \mathrm{V}}{m}$

The \% removal efficiency (RE) of removal dye (Eq. 2) were calculated as follows:
$\% \mathrm{RE}=\frac{(\mathrm{Co}-\mathrm{Ce}) \mathrm{100 \%}}{\mathrm{Co}}$

Where Co and Ce were the initial and equilibrium dye concentrations $(\mathrm{mg} / \mathrm{L}), \mathrm{m}$ was the mass of $\mathrm{ES}+\mathrm{M}(\mathrm{g})$, and $\mathrm{V}$ was the volume of IC dye solution (L).

\section{Results and discussion}

\subsection{Effect of pH solution}

Adsorption is a complex process depending on several interactions such as electrostatic and non-electrostatic interactions. The $\mathrm{pH}$ effects were investigated by varying the $\mathrm{pH}$ from 2 to 10 were presented in Figure 2. The optimum adsorption of Methylene Blue has occurred at pH 8 and Indigo carmine at pH 10. Comparison of adsorption cationic and anionic by $\mathrm{ES}+\mathrm{M}$ in Figure 2 showed that adsorption capacity and \% RE of Methylene blue higher than Indigo carmine. 
Generally, the surface area of adsorbent will be positive at low $\mathrm{pH}$ and can adsorb anionic dyes ${ }^{41,42}$. But the existence of $\mathrm{CaCO}_{3}$ the solution will be slightly alkaline. The low adsorption capacity of methylene blue at acidic $\mathrm{pH}$ might increase due to the presence of excess $\mathrm{H}^{+}$ions competing with positively charged cationic dye for the available adsorption sites ${ }^{43}$. So the optimum ES+M to adsorb Methylene Blue at $\mathrm{pH}$ 8. Another literature report that the adsorption of Brillian green as the cationic dye was optimum to $\mathrm{pH} 9$ onto eggshell ${ }^{44}$.

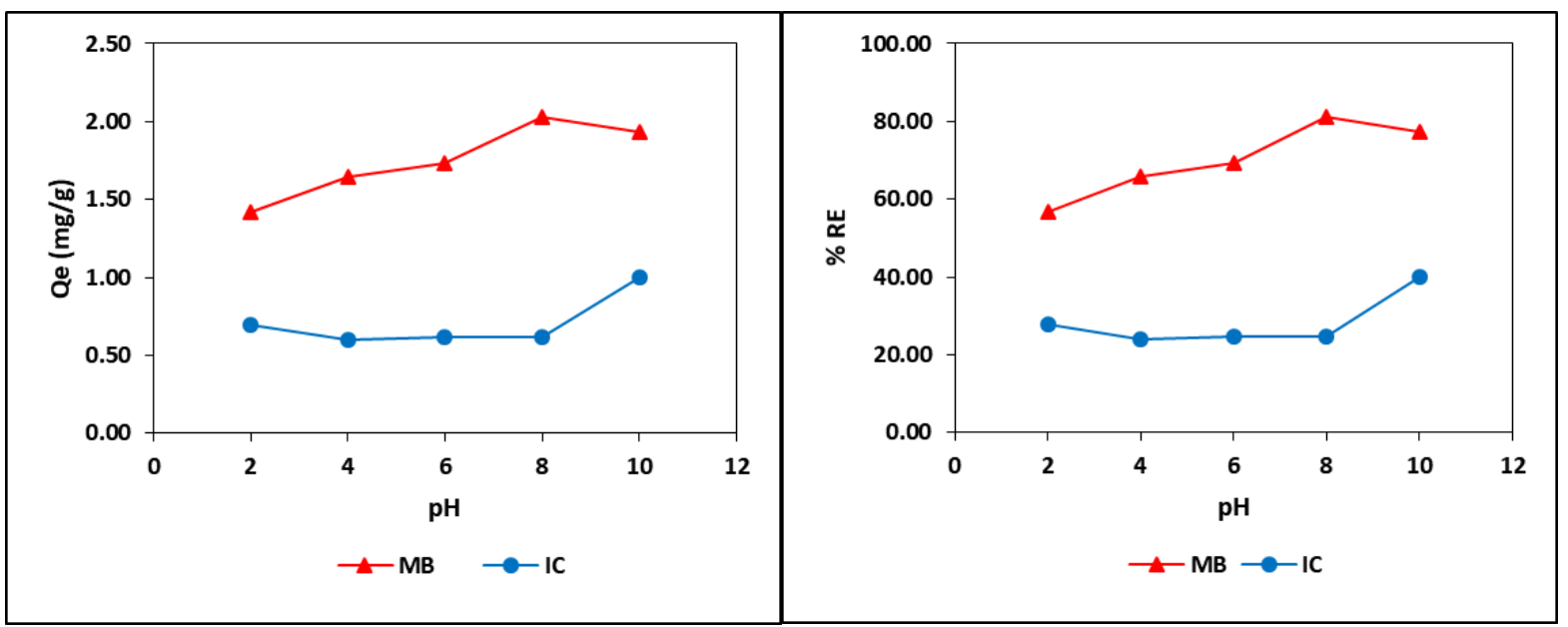

Figure 2. Effect of $\mathrm{pH}$ solution to adsorption capacity and \% RE to removal Methylene Blue and Indigo Carmine

Meanwhile, the adsorption capacity for ES+M to adsorb Indigo carmine has occurred at $\mathrm{pH}$ 10. The present of $\mathrm{HNO} 3$ may cause it in low $\mathrm{pH}$ make the $\mathrm{CaCO}_{3}$ will be release $\mathrm{CO}_{2}{ }^{45}$ with reaction equation 1 , so the binding could not occur, at the acid condition. Besides that, the present of $\mathrm{CaCO}_{3}$ in different initial $\mathrm{pH}$ can influence the solution of $\mathrm{ES}+\mathrm{M}$ in alkaline condition ${ }^{38}$

$$
\mathrm{CaCO}_{3}+2 \mathrm{HNO}_{3} \rightarrow \mathrm{Ca}\left(\mathrm{NO}_{3}\right)_{2}+\mathrm{H}_{2} \mathrm{O}+\mathrm{CO}_{2}(1)
$$

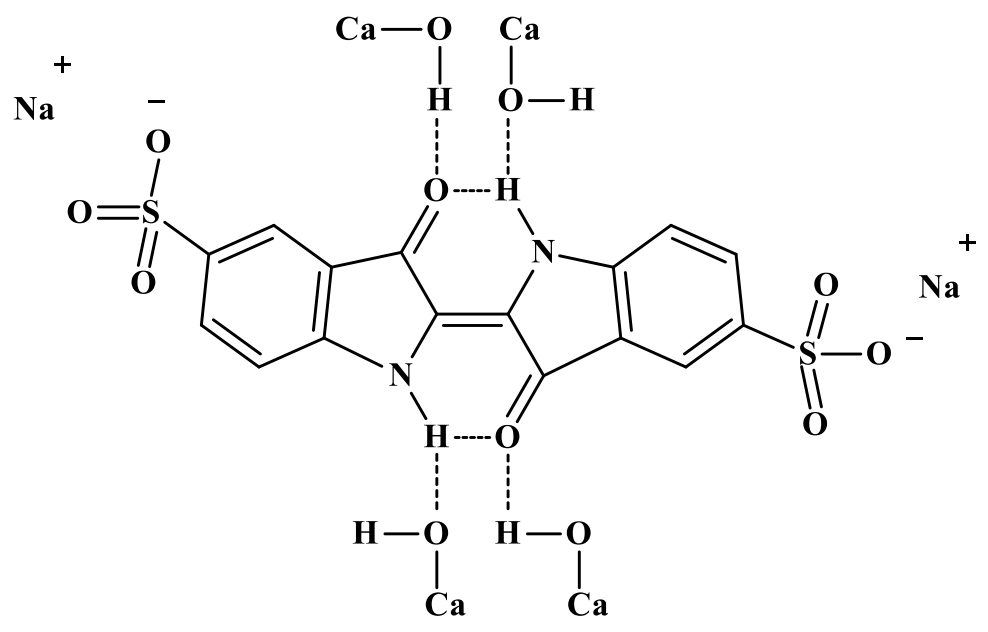

Figure 3. Mechanism of interaction of Indigo carmine and Calcium hydroxide

\subsection{Effect of contact time}

The adsorption capacity and \% RE of Methylene Blue in Figure 4. was 30 minutes similar to Ngadi et al. in 30 minutes ${ }^{43}$. The optimum contact time of ES+M to adsorb Indigo carmine occurred in 15 minutes. It caused of the two ions from sulfonate group at Indigo
The increase adsorption capacity equal with the increase of the $\mathrm{pH}$. It caused of the electrostatic force of attractions between the indigo carmine dye and calcium hydroxide with mechanism reaction in Figure 3. Ramesh et al. also reported that adsorption Indigo carmine by calcium hydroxide was effective at pH $12^{46}$. 


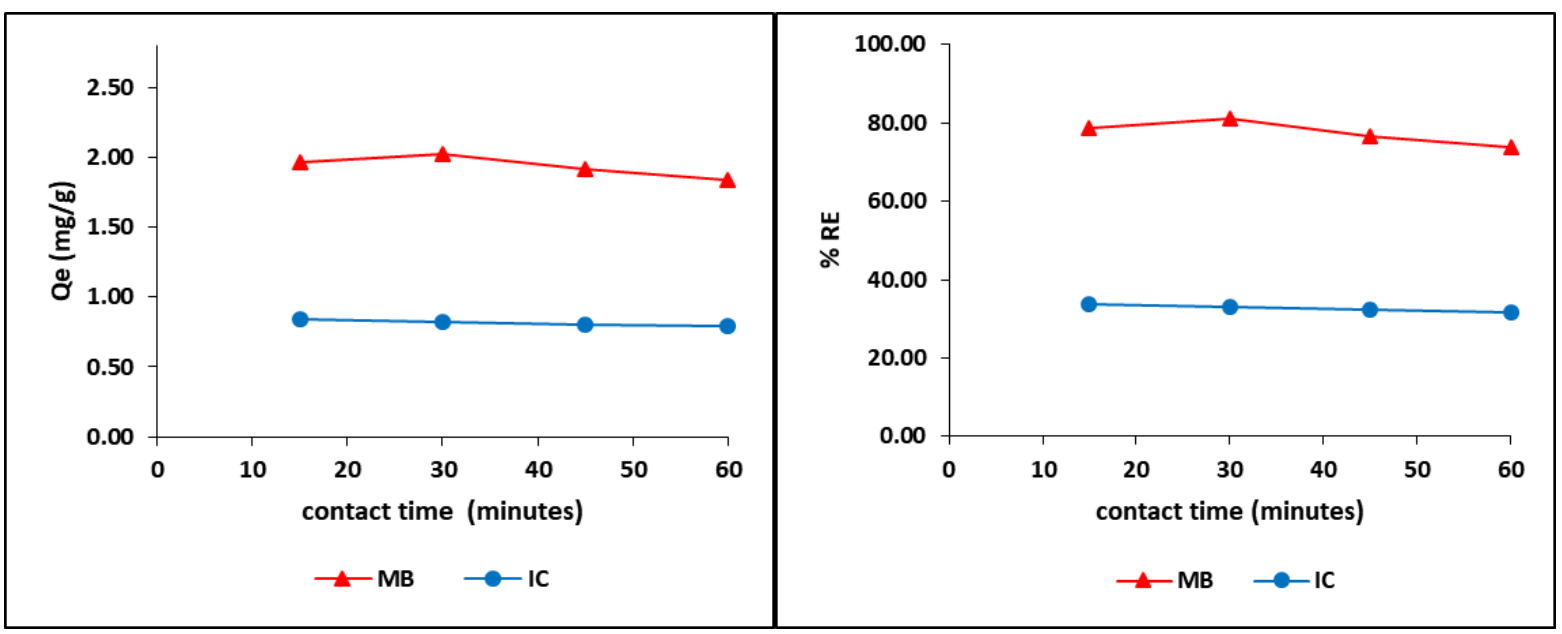

Figure 4. Effect of contact time to adsorption capacity and \% RE to removal Methylene Blue and Indigo Carmine

\subsection{Effect initial concentration of dye}

The effect of the initial concentration of dyes was studied in the range of $10-50 \mathrm{mg} / \mathrm{L}$. Increasing of Methylene Blue and Indigo Carmine concentration increased the adsorption capacity of ES+M until equilibrium and saturated. Figure 5 showed that the optimum adsorption capacity of Methylene Blue onto $\mathrm{ES}+\mathrm{M}$ was $9.03 \mathrm{mg} / \mathrm{L}$, and Indigo carmine was
$5.79 \mathrm{mg} / \mathrm{L}$. Its adsorption capacity high enough comparing with eggshell adsorb fluoride ${ }^{32}$. Meanwhile, the more top of initial concentration, the lower removal efficiency of methylene blue and indigo carmine. It occurred that higher concentration of dyes could be saturated of the active site of ES+M, so that removal efficiency both of them would be decreased.
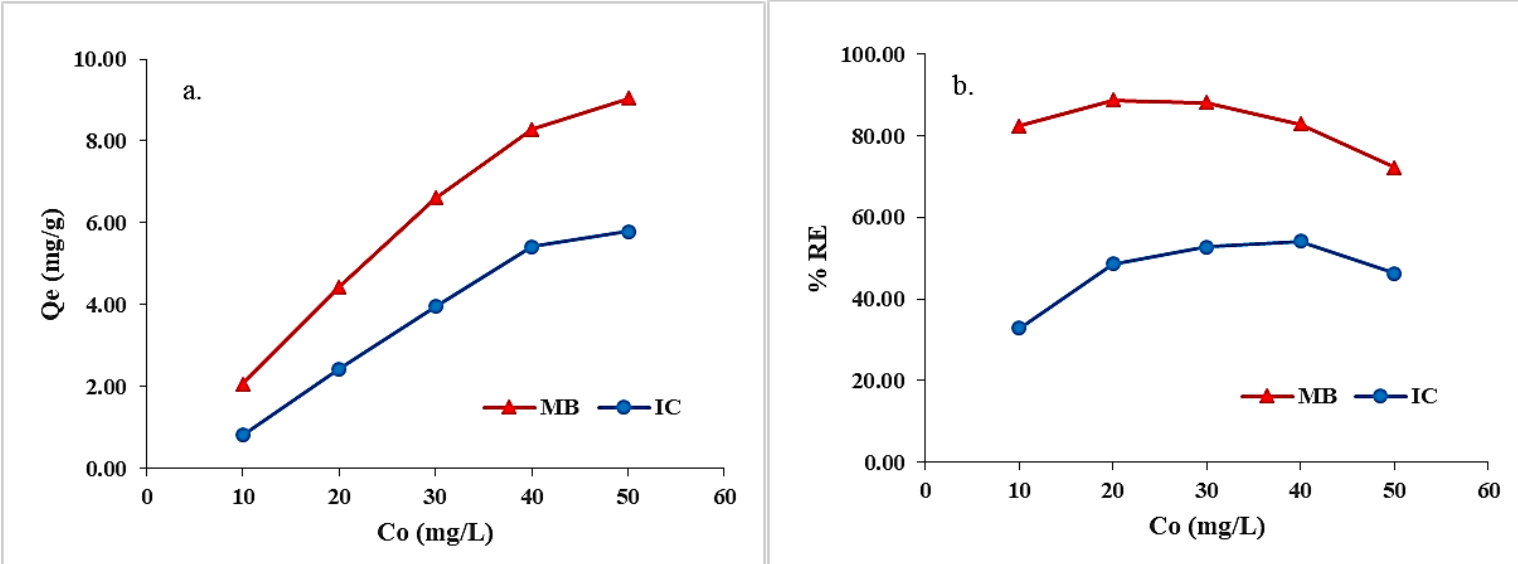

Figure 5. Effect of the initial concentration of dyes on adsorption capacity and \% RE to removal Methylene Blue and Indigo Carmine by ES+M

\subsection{Effect mass of adsorbent}

In Figure 6 showed the greater mass of adsorbent, the higher the adsorption capacity and \% RE Methylene Blue by ES+M. In this case the optimum mass of adsorption of Methylene Blue at $1 \mathrm{~g}$ of adsorbent. This phenomenon refers to increasing the surface area of $\mathrm{ES}+\mathrm{M}$ and the availability of more adsorption sites to interact with the dye. Whereas Indigo Carmine, the more adsorbent mass does not always increase the adsorption capacity and \% RE. The optimum mass of adsorbent to adsorb Indigo carmine is $0.5 \mathrm{~g}$. If more than it, the interaction of Indigo Carmine and adsorbent will be released due to the collision between adsorbents, thereby disrupting the adsorption of indigo carmine. 


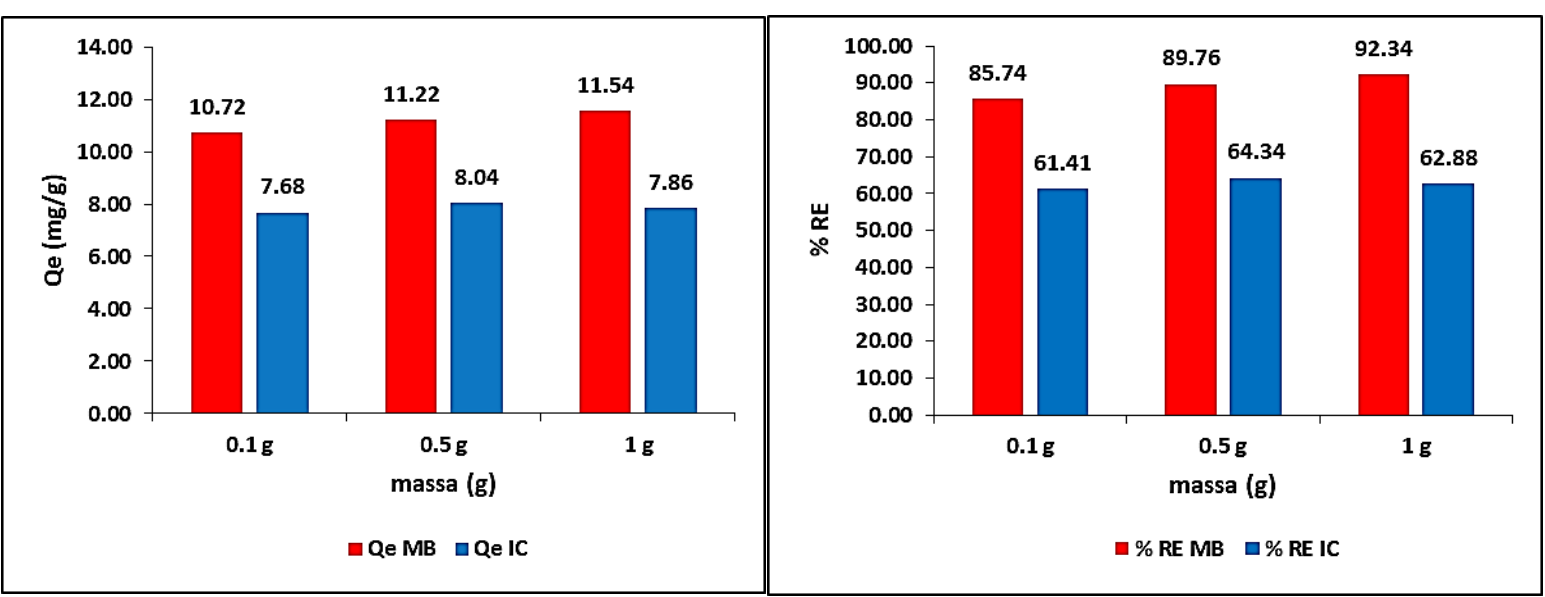

Figure 6. Effect mass of adsorbent to adsorption capacity and \% RE to removal Methylene Blue and Indigo Carmine

\subsection{FTIR Analysis}

Characterization of ES+M to adsorb dyes shown the presence of $\mathrm{CaCO}_{3}$ and proteins that have amino acids to binding with the dyes ${ }^{47}$. In Figure 7 could be seen that the shift of wavenumber of ES+M before and after adsorbing Methylene Blue and Indigo Carmine. There is a shift in the wavenumber such as at $\quad 675$ - $1000 \mathrm{~cm}^{-1}$ the existence of $-\mathrm{C}=\mathrm{H}$ bending, $\mathrm{N}-\mathrm{H}$ at $867 \mathrm{~cm}^{-1}, \mathrm{C}-\mathrm{C}$ vibration at $710 \mathrm{~cm}^{-148}, \mathrm{~S}=\mathrm{O}$ at 1075 $\mathrm{cm}^{-1}$ after adsorbing Methylene Blue and $\mathrm{S}=\mathrm{O}$ at
$1077 \mathrm{~cm}^{-1}$ after adsorbing Indigo Carmine, $1400-1600 \mathrm{~cm}^{-1}$ indicating the presence of the $\mathrm{CH}$ bending group $\mathrm{C}=\mathrm{C}$ alkene. The presence of the $\mathrm{C}=\mathrm{O}$ group at $1795 \mathrm{~cm}^{-1}$ and carbonate group $1400 \mathrm{~cm}^{-1}$, $\mathrm{C}-\mathrm{H}$ vibration organic layers with an amino acid in eggshell at $2978 \mathrm{~cm}^{-1}, \mathrm{~S}-\mathrm{H}$ thiols at $2510-2600$. The present of $\mathrm{O}-\mathrm{H}$ from the carboxylic acid and $\mathrm{H}_{2} \mathrm{O}$ as a result of the reaction of $\mathrm{CaCO}_{3}$ with $\mathrm{HNO}_{3}$ at 3670 and $3669 \mathrm{~cm}^{-1} 45,49$.

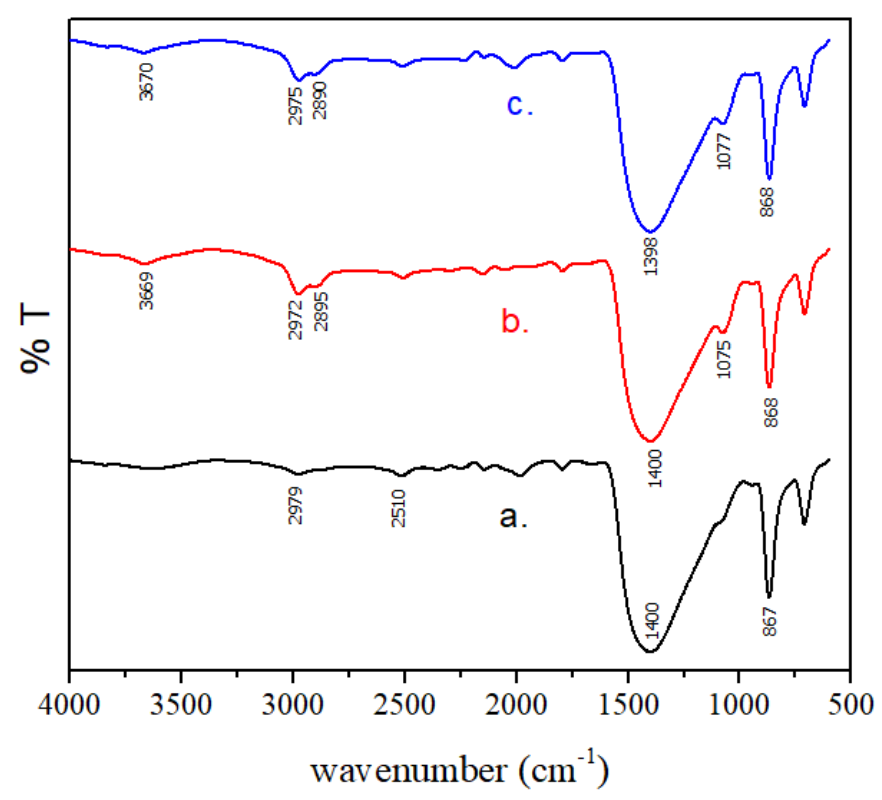

Figure 7. FTIR of ES+M before adsorbing MB and IC (a), after adsorbing MB (b), and after adsorbing IC (c)

\subsection{XRF Analysis}

Most of ES+M containing $\mathrm{CaCO}_{3}$ from with $97.563 \%$ and a small number of other minerals. In Table 1 could be seen that several elements in ES+M would be decreased and increased before and after adsorption. It means that occurred the interaction between ES+M and dyes. After adsorbing Methylene Blue as cationic dye increased the composition of $\mathrm{Ag}, \mathrm{P}_{2} \mathrm{O}_{5}$ and after adsorbing Indigo Carmine as an anionic dye, the composition of $S$ increased caused of Indigo Carmine consist $\mathrm{S}$ element in its structure. From data can be seen that the amount of the protein from membrane eggshell to interact with dyes only small. It also effects the adsorption capacity of ES+M in binding with the dyes. 
Table 1. XRF analysis of ES+M before and after adsorb Methylene Blue and Indigo Carmine.

\begin{tabular}{|c|c|c|c|}
\hline Element in compound & Before adsorption (\%) & $\begin{array}{c}\text { After adsorbing MB } \\
(\boldsymbol{\%})\end{array}$ & After adsorbing IC (\%) \\
\hline $\mathbf{C a O}$ & 97.563 & 97.468 & 97.591 \\
\hline $\mathbf{P}_{\mathbf{2}} \mathbf{O}_{5}$ & 0.943 & 0.978 & 0.81 \\
\hline $\mathbf{S O}_{3}$ & 0.299 & 0.211 & 0.547 \\
\hline $\mathbf{A g}$ & 0.679 & 0.717 & 0.719 \\
\hline $\mathbf{A l}$ & 0.244 & 0.27 & 0.219 \\
\hline
\end{tabular}

\section{Conclusions}

In this study reported that the optimum adsorption $\mathrm{MB}$ and IC used ES+M occurred at $\mathrm{pH} 8$ and 10, contact time 30 and 15 minutes, in $50 \mathrm{mg} . \mathrm{L}^{-1}$ and mass adsorbent $1 \mathrm{~g}$ and $0.5 \mathrm{~g}$ respectively.

For all treatment indicated that Methylene Blue as cationic dye higher adsorption capacity and higher \% Removal efficiency than Indigo carmine as an anionic dye. The phenomenon caused of the presence of the membrane of the eggshell has more functional group such as hydroxyl, carboxyl and sulfhydryl to interacted with Methylene blue, whereas amine group and the $\mathrm{Ca}(\mathrm{OH})_{2}$ in solution only interact with Indigo Carmine. However, we can conclude that ES+M could be used to remove Methylene Blue and Indigo Carmine as a low-cost adsorbent that easy to obtain, inexpensive, and the process was so fast.

\section{Acknowledgement}

We acknowledgement to Directorate of research and community service. Directorate General of research and development strengthening. Ministry of technology research and higher education under the 2019 budget year research contract. No: 010/L10/AK.04/KONTRAK-PENELITIAN/2019.

\section{References}

1- K. Sharma, A. Dalai, R. Vyas, Removal of synthetic dyes from multicomponent industrial wastewaters, Rev. Chem. Eng., 2017, 34, 107-134.

2- R. Zein, R. Suhaili, F. Earnestly, Indrawati, E. Munaf, Removal of $\mathrm{Pb}(\mathrm{II}), \mathrm{Cd}(\mathrm{II})$ and $\mathrm{Co}(\mathrm{II})$ from aqueous solution using Garcinia mangostana L. fruit shell, Journal of Hazardous Materials, 2010, 181, 52-56.

3- W. Wang, G. Huang, C. An, X. Xin, Y. Zhang, $\mathrm{X}$. Liu, Transport behaviors of anionic azo dyes at interface between surfactant-modified flax shives and aqueous solution: Synchrotron infrared and adsorption studies, Applied Surface Science, 2017, 405, 119-128.

4- E. Fosso-Kankeu, A. Webster, I. O. Ntwampe, F. B. Waanders, Coagulation/Flocculation Potential of Polyaluminium Chloride and Bentonite Clay Tested in the Removal of Methyl Red and Crystal Violet, Arabian Journal for Science and Engineering, 2017, 42, 1389-1397.
5- O. Gulnaz, A. Kaya, F. Matyar, B. Arikan, Sorption of basic dyes from aqueous solution by activated sludge, Journal of Hazardous Materials, 2004, 108, 183-188.

6- N. S. Maurya, A. K. Mittal, P. Cornel, E. Rother, Biosorption of dyes using dead macro fungi: Effect of dye structure, ionic strength and $\mathrm{pH}$, Bioresource Technology, 2006, 97, 512-521.

7- Zilfa, Rahmayeni, Y. Stiadi, Adril, Utilization of natural zeolite clinoptilolite-Ca as support of $\mathrm{ZnO}$ catalyst for congo-red degradation and congo-red waste applications with photolysis, Orient. J. Chem., 2018, 34, 887-893.

8- Rahmayeni, S. Arief, N. Jamarun, Emriadi, Y. Stiadi, Magnetically separable $\mathrm{ZnO}-\mathrm{MnFe} 2 \mathrm{O} 4$ nanocomposites synthesized in organic-free media for dye degradation under natural sunlight, Orient. J. Chem., 2017, 33, 2758-2765.

9- W. Chen, W. Lu, Y. Yao, M. Xu, Highly efficient decomposition of organic dyes by aqueous-fiber phase transfer and in situ catalytic oxidation using fiber-supported cobalt phthalocyanine, Environmental Science and Technology, 2007, 41, 6240-6245.

10-M. F. Abid, M. A. Zablouk, A. M. AbidAlameer, Experimental study of dye removal from industrial wastewater by membrane technologies of reverse osmosis and nanofiltration, Iranian Journal of Environmental Health Science and Engineering, 2012, 9, 1-9.

11-L. Hevira, R. Zein, P. Ramadhani, Review Metoda Adsorpsi pada penyerapan ion logam dan zat warna dalam limbah cair, Jurnal Sains dan Terapan Kimia, 2019, 13, 39-58.

12-M. M. Higarashi, R. M. Mattei, Application of natural adsorbents to remove nutrients from swine facility effluent, Livestock Research for Rural Development, 2009, 21.

13-S. Wongtangtintan, L. Neeratanaphan, P. Ruchuwararak, S. Suksangawong, U. Tengjaroenkul, P. Sukon, B. Tengjaroenkul, Comparative study of aflatoxin B1 adsorption by Thai bentonite and commercial toxin binders at different temperatures in vitro, Livestock Research for Rural Development, 2016, 28, 1-8.

14-S. M. Al-Mahmoud, Adsorption of some aliphatic dicarboxylic acids on zinc oxide: A kinetic and Thermodynamic Study, Baghdad Science Journal, 2019, 16, 892-897. 
15-I. Lebkiri, B. Abbou, L. Kadiri, A. Ouass, Y. Essaadaoui, A. Habssaoui, E. H. Rifi, A. Lebkiri, Removal of methylene blue dye from aqueous solution using a superabsorbant hydrogel the polyacrylamide: Isotherms and kinetic studies, Mediterr.J.Chem., 2019, 9, 337-346.

16-K. Pyrzynska, Removal of cadmium from wastewaters with low-cost adsorbents, Journal of Environmental Chemical Engineering, 2019, 7, 102795. doi:10.1016/j.jece.2018.11.040.

17-H. I. Albroomi, M. A. Elsayed, A. Baraka, M. A. Abdelmaged, Batch and fixed-bed adsorption of tartrazine azo-dye onto activated carbon prepared from apricot stones, Applied Water Science, 2017, 7, 2063-2074.

18-M. Shanker, T. Chinniagounder, Adsorption of Reactive Dye Using Low-Cost Adsorbent: Cocoa (Theobroma Cacao) Shell, World Journal of Applied Environmental Chemistry, 2017, 1, 22-29.

19-W. S. Alencar, E. Acayanka, E. C. Lima, B. Royer, F. E. de Souza, J. Lameira, C. N. Alves, Application of Mangifera indica (mango) seeds as a biosorbent for removal of Victazol Orange 3R dye from aqueous solution and study of the biosorption mechanism, Chemical Engineering Journal, 2012, 209, 577-588.

20-J. J. Salazar-Rabago, R. Leyva-Ramos, J. RiveraUtrilla, R. Ocampo-Perez, F. J. Cerino-Cordova, Biosorption mechanism of Methylene Blue from aqueous solution onto White Pine (Pinus duranguense) sawdust: Effect of operating conditions, Sustainable Environment Research, 2017, 27, 32-40.

21-M. Arami, N. Y. Limaee, N. M. Mahmoodi, N. S. Tabrizi, Removal of dyes from colored textile wastewater by orange peel adsorbent: Equilibrium and kinetic studies, Journal of Colloid and Interface Science, 2005, 288, 371-376.

22-C. Djelloul, O. Hamdaoui, Dynamic adsorption of methylene blue by melon peel in fixed-bed columns, Desalination and Water Treatment, 2015, 56, 2966-2975.

23-S. Guiza, K. Ghiloufi, F. M. Bagane, S. O. Ibnelkhattab, Utilization of waste Tunisian palm tree date as a low-cost adsorbent for the removal of dyes from textile wastewater, Mediterranean Journal of Chemistry, 2014, 3, 1044-1052.

24-A. K. Nayak, A. Pal, Rapid and highperformance adsorptive removal of hazardous acridine orange from the aqueous environment using Abelmoschus esculentus seed powder: Single- and multi-parameter optimization studies, Journal of Environmental Management, 2018, 217, 573-591.

25-J. O. Ighalo, A. G. Adeniyi, Adsorption of pollutants by plant bark derived adsorbents: An empirical review, Journal of Water Process Engineering, 2020, 35, 101228.

26-S. S. Salih, T. K. Ghosh, Preparation and characterization of bioadsorbent beads for chromium and zinc ions adsorption, Cogent Environmental Science, 2017, 3, 1-14. doi:10.1080/23311843.2017.1401577.

27-S. S. Salih, A. Mahdi, M. Kadhom, T. K. Ghosh, Competitive adsorption of As(III) and As(V) onto chitosan/diatomaceous earth adsorbent, Journal of Environmental Chemical Engineering, 2019, 7, 103407.

28-S. S. Salih, T. K. Ghosh, Preparation and Characterization of Chitosan-Coated Diatomaceous Earth for Hexavalent Chromium Removal, Environmental Processes, 2018, 5, 23-39.

29-F. S. Murakami, P. O. Rodrigues, C. M. T. De Campos, M. A. S. Silva, Physicochemical study of $\mathrm{CaCO} 3$ from eggshells, Ciencia e Tecnologia de Alimentos, 2007, 27, 658-662.

30-N. Buksh, C. Yun, X. Ping, G. H. Jhatial, S. Yanhai, Chicken Eggshell as a Potential Ecofriendly, Low-cost Sorbent: A Mini-Review, Journal of Environment and Earth Science, 2018, 8, 28-39.

31-H. Faridi, A. Arabhosseini, Application of eggshell wastes as valuable and utilizable products: A review, Research in Agricultural Engineering, 2018, 64, 104-114.

32-R. Bhaumik, N. K. Mondal, B. Das, P. Roy, K. C. Pal, C. Das, A. Banerjee, J. K. Datta, Eggshell powder as an adsorbent for removal of fluoride from aqueous solution: Equilibrium, kinetic and thermodynamic studies, E-Journal of Chemistry, 2012, 9, 1457-1480.

33-G. De Angelis, L. Medeghini, A. M. Conte, S. Mignardi, Recycling of eggshell waste into low-cost adsorbent for Ni removal from wastewater, Journal of Cleaner Production, 2017, 164, 1497-1506.

34-O. A. Habeeb, F. Yasin, U. A. Danhassan, Characterization and application of chicken eggshell as green adsorbents for removal of $\mathrm{H} 2 \mathrm{~S}$ from wastewaters, Journal of Environmental Science, Toxicology and Food Technology, 2014, 8, 7-12.

35-D. D. Salman, W. S. Ulaiwi, N. M. Tariq, Determination the optimal conditions of Methylene blue adsorption by the chicken eggshell membrane, International Journal of Poultry Science, 2012, 11, 391-396.

36-J. Carvalho, J. Araujo, F. Castro, Alternative lowcost adsorbent for water and wastewater decontamination derived from eggshell waste: An overview, Waste and Biomass Valorization, 2011, 2, 157-167.

37-E. Steelyana, Batik, A Beautiful Cultural Heritage that Preserves Culture and Supporteconomic Development in Indonesia, Binus Business Review, 2012, 3, 116.

38-N. Pramanpol, N. Nitayapat, Adsorption of reactive dye by eggshell and its membrane, Kasetsart Journal - Natural Science, 2006, 40, 192-197. 
39-L. Hevira, E. Munaf, R. Zein, The use of Terminalia catappa L. fruit shell as biosorbent for the removal of $\mathrm{Pb}$ (II), $\mathrm{Cd}$ (II) and $\mathrm{Cu}$ (II) ion in liquid waste, Journal of Chemical and Pharmaceutical Research, 2015, 7, 79-89.

40-L. Hevira, R. Zein, E. Munaf, Efisiensi Penyerapan ION Logam Terhadap pH dan Waktu Kontak Menggunakan Cangkang Ketapang, Jurnal Katalisator, 2019, 4, 42-52.

41-M. C. Somasekhara Reddy, L. Sivaramakrishna, A. Varada Reddy, The use of agricultural waste material, Jujuba seeds for the removal of anionic dye (Congo red) from aqueous medium, Journal of Hazardous Materials, 2012, 203-204, 118-127.

42-J. K. Fatombi, E. A. Idohou, S. A. Osseni, I. Agani, D. Neumeyer, M. Verelst, R. Mauricot, T. Aminou, Adsorption of Indigo Carmine from Aqueous Solution by Chitosan and Chitosan/Activated Carbon Composite: Kinetics, Isotherms and Thermodynamic Studies, Fibers and Polymers, 2019, 20, 1820-1832.

43-N. Ngadi, C. C. Ee, N. A. Yuszff, Removal of Methylene Blue Dye by Using Eggshell Powder, Jurnal Teknologi (Sciences and Engineering), 2013, 65, 63-71.

44-R. Kobiraj, N. Gupta, A. K. Kushwaha, M. C. Chattopadhyaya, Determination of equilibrium, kinetic and thermodynamic parameters for the adsorption of brilliant green dye from aqueous solutions onto eggshell powder, Indian Journal of Chemical Technology, 2012, 19, 26-31.

45-A. L. Goodman, G. M. Underwood, V. H. Grassian, A laboratory study of the heterogeneous reaction of nitric acid on calcium carbonate particles, Journal of Geophysical Research, 2000, 105, 29053-29064.

46-T. N. Ramesh, D. V. Kirana, A. Ashwini, T. R. Manasa, Calcium hydroxide as a low-cost adsorbent for the effective removal of indigo carmine dye in water, Journal of Saudi Chemical Society, 2017, 21, 165-171.

47-M. T. Hincke, Y. Nys, J. Gautron, K. Mann, A. B. Rodriguez-Navarro, M. D. McKee, The eggshell: Structure, composition and mineralization, Frontiers in Bioscience, 2012, 17 , 1266-1280.

48-H. Daraei, A. Mittal, J. Mittal, H. Kamali, Optimization of $\mathrm{Cr}(\mathrm{VI})$ removal onto biosorbent eggshell membrane: Experimental \& theoretical approaches, Desalination and Water Treatment, 2014, 52, 1307-1315.

49- Y. Nakano, K. Takeshita, T. Tsutsumi, Adsorption mechanism of hexavalent chromium by redox within the condensed-tannin gel, Water Research, 2001, 35, 496-500. 